\title{
The Fate of Bad Things
}

\section{SCOTT HERRING}

INDIANA UNIVERSITY

\author{
Kevin M. Moist and David Banash (eds) \\ Contemporary Collecting: Objects, Practices, and the Fate of Things
}

Scarecrow Press, Maryland, 2013

ISBN 9780810891135

RRP US\$72.00

As its title attests, the thirteen essays gathered into Moist and Banash's Contemporary Collecting advance an interdisciplinary field that scholars have come to refer to as collecting studies. To do so, the collection extends earlier theoristsWalter Benjamin, Susan Stewart, Jean Baudrillard, Mieke Bal, Susan M. Pearce, Russell W. Belk and James Clifford-who each delved into connections between modern materiality, our craving for things, and the cultivation of personal belongings for public spectacle and semi-private viewing. An incomplete bibliography from these foundational thinkers would include Benjamin's 'Unpacking My Library' (1931), Baudrillard's The System of Objects (1968), Belk's 'Possessions and the Extended Self' (1988), and Stewart's On Longing (1993). ${ }^{1}$ The book's ISSN 1837-8692

Cultural Studies Review 2014. ( 2014 Scott Herring. This is an Open Access article distributed under the terms of the Creative Commons Attribution 4.0 Unported (CC BY 4.0) License

(https://creativecommons.org/licenses/by/4.0/), allowing third parties to copy and redistribute the material in any medium or format and to remix, transform, and build upon the material for any purpose, even commercially, provided the original work is properly cited and states its license.

Citation: Cultural Studies Review (CSR) 2014, 20, 4051, http://dx.doi.org/10.5130/csr.v20i2.4051 
introduction rightly acknowledges its intellectual debts to some of these writers before augmenting their trailblazing theorisations with case studies that focus on the latest versions of amassing as well as fresh takes on longstanding modes of object acquisition.

If Contemporary Collecting aspires to refine a field-in-progress, it largely succeeds due to its multidisciplinarity. Indeed, given that its contributors work across cultural studies, theatre studies, art history, literary studies, philosophy and material culture studies, it would be hard for the book to disappoint on the methodological front. Divided into four sections-'Collecting in a Virtual World', 'Changing Relationships with Things', 'Collecting and Identity, Personal and Political', and 'Collecting Practices and Cultural Hierarchies'-the various contributors mull over an impressive assortment of stuff from MP3 collections to the pocket candy dispensers at the heart of PEZhead culture. Philip J. Hutchinson considers live-to-air entertainment shows broadcast on local television stations in the late 1940s through the mid-1970s that belatedly claim a collectable life via websites devoted to television ephemera. Terri Baker's piece on 'the Victorian woman collector' and institutions such as the Folger Shakespeare Library attends to matters of gender and feminism (even as more needs to be done on this subject within and without this book). (177) Moist completes Contemporary Collecting with his analysis of record album collecting.

As they chart newfangled pathways into the cultural poetics of getting, selecting and arranging, these case studies address our holding on to things and, more poignantly, our letting them go. Though none of the authors frame their interventions as such, many of them have fellow travellers in the field of affect studies. They frequently engage the emotional life of collecting, particularly the loss of personal belongings, and some are doused in grief whether purposefully or not. Discussing the erasure of his digitised music collections, Marcus Boon acknowledges 'the fact of my loss'. (5) Surveying the 'great pleasure' and sorrow that older television viewers feel when they come across uploaded items from mid-century television shows, Hutchinson records how one fan shook with emotion while browsing the partial archive. (42) At these moments it becomes clear that collecting is a means of reigniting a relation to a lost era, a reach into childhood, a way to stitch together life narrative through ephemera. Collecting collects on more than one scale: 
it collates a sense of subjectivity across a life span, a historical moment, a generation's structure of feelings. These are by no means new observations about the social life of things but, given how many chapters insist that collecting is both an intimate act and a group phenomenon, the concern with positive and negative affect offers us a rich resource for thinking through the emotional complexities of late modern material cultures.

The emphasis on emotion is the sharpest contribution that Contemporary Collecting in its entirety grants collecting studies. That said, I wish that Moist and Banash had spent more time delineating not only the personal and political feelings that saturate collecting, or novel collections such as digitised archives of music, but also the troubling perversity that often accompanies accumulation. I mean perversity to register both incriminatory moralism as well as recuperative queerness. ${ }^{2}$ The editors might have said more about this facet of collecting, especially since nearly a quarter of the book addresses the profound eccentricity of acquisitions and ownership. While one contributor cites James Clifford on 'the good collector', far more dwell on the 'deviant relation' to things said to characterise 'the obsessive, the miser'. (71) In a chapter evocatively titled 'Suited for Nothing: Collecting Secondhand', William Davies King reflects that his own personal treasures have their roots in a 'profligate self' (81) and comprise 'a bit of a freak show'. (88) King is also mindful of how others cast 'excessive possession' as 'moral weakness'. (97) This anxiety about the perversity of collecting is also evident in Stanley Cavell's 1998 essay 'The World as Things: Collecting Thoughts on Collecting' which this volume reprints. Typically Cavellian with crystal-clear prose, the piece nevertheless ripples with worry when it encounters disorderly collections said to reflect 'a madness of misanthropy'. (127) Yet, at the same time that he figuratively distances himself from these mad collections, Cavell also asks us 'to imagine the alien' and acknowledge that 'my interests may make me incomprehensible to others'. (117) Cavell's 'alien' connotes an individual's social otherness but it also points to how our collections can queerly misalign us with material norms. While Cavell might be horrified at what Susan Stewart refers to as 'insane collection', Contemporary Collecting suggests better ways of comprehending non-normative collecting. ${ }^{3}$

Two other examples corroborate this reparative interest in previously demonised enthusiasms that fall outside the parameters of social or political 
respectability. In a chapter on National Socialist cigarette cards, Mechtild Widrich examines how 'these cards fused youth culture and propaganda photography with the forceful means of dissemination that was cigarette packaging'. (152) Widrich's recreation of the distribution patterns of these Nazi cigarette cards and her interpretation of the archive they leave are impressive, but I am equally intrigued that the photographic reproductions of these cards come 'courtesy of Mechtild Widrich'. Whether or not the cigarette card collection is in Widrich's possession, the act of photographing them cannot stand clear of the collating impulse it interprets. I wonder, therefore, what emotional or psychological impulse propelled Widrich toward these 'morbid collectibles,' to use Sara Knox's term. Knox's phrase can be found in 'The Serial Killer as Collector', her contribution to Leah Dilworth's Acts of Possession: Collecting in America, an excellent anthology that Moist and Banash reference but could have further engaged. ${ }^{4}$ The collecting of 'Nazi knick-knacks' and other morbid things should not be ignored nor under-theorised in favour of case studies that focus on 'good' collecting. ${ }^{5}$ (155)

The final example, and what I take to be the finest essay of the bunch, reveals what can be gained by attending to deviant collecting. Mary Titus looks at House on the Rock, a quizzical mess of a building that Alex Jordan Jr built in Spring Green, Wisconsin, as a riposte to its near neighbour, Frank Lloyd Wright's modernist masterwork Taliesin. Now a midwest tourist attraction in its own right, Jordan's architectural horror is a 'wildly imaginative structure' that across time has become 'stuffed with vast collections whose contents-carousels, sea creatures, doll houses-trumpets a low-brow raspberry at Wright's high-minded design'. (213) Though Jordan has been derided as a 'pathological collector', (219) Titus is more interested in how House on the Rock continues to stupefy those that are drawn to it. The House on the Rock, she finds, spurs 'anxiety and even hostility' (224) in tourists who are unable to look away from its 'parodically curated accumulations' (223) even as, or perhaps because, they so unsettle them.

In her closing paragraph, Titus links the contents of House on the Rock 'to the tangled heaps and bursting trash bags of "Hoarders"', a cancelled US reality television show that makes entertainment of compulsive acquisition. (225) Titus's essay sketches a material genealogy for what we might refer to as the fate of bad things. More needs to be done with the besmirched figure of the 'pathological 
collector' in the ever-growing field of collecting studies. Without doubt Contemporary Collecting lays strong groundwork for this line of thinking, while also contributing to sonic studies, television studies, memory studies, and studies of the built environment. While its disciplinary credentials are in good standing, it likewise gestures to the interpretive possibilities of holding on to trash.

Scott Herring is Associate Professor of English at Indiana University, Bloomington. He is the author, most recently, of The Hoarders: Material Deviance in Modern American Culture (2014) and Another Country: Queer Anti-Urbanism (2010).

\footnotetext{
-NOTES

1 Walter Benjamin, 'Unpacking My Library: A Talk about Book Collecting,' in Illuminations, ed. Hannah Arendt, trans. Harry Zohn, Schocken Books, New York, 1969, pp. 59-67; Jean Baudrillard, The System of Objects, trans. James Benedict, Verso, London, 1996; Russell W. Belk, 'Possessions and the Extended Self', Journal of Consumer Research, vol. 15, no. 2, 1988, pp. 139-68; Susan Stewart, On Longing: Narratives of the Miniature, the Gigantic, the Souvenir, the Collection, Duke University Press, 1993.

2 Think, for example, of Baudrillard's claim that 'the possession of objects and the passion for them is, shall we say, a tempered mode of sexual perversion.' Baudrillard, p. 99.

3 Stewart, p. 154.

${ }^{4}$ Sara Knox, 'The Serial Killer as Collector,' in Acts of Possession: Collecting in America, ed. Leah Dilworth, Rutgers University Press, New Brunswick, NJ, 2003, p. 297.

${ }^{5}$ For an extensive discussion of this subject, see Gregory Maertz, 'Exhibiting Nazi Artifacts and Challenging Traditional Museum Culture: A Conversation with Mitchell Wolfson Jr.,' in Dilworth (ed.), 267-85.

\section{-BIBLIOGRAPHY}

Baudrillard, J., The System of Objects, trans. James Benedict, Verso, London, 1996.

Belk, R. W., 'Possessions and the Extended Self', Journal of Consumer Research, vol. 15, no. 2, 1988. doi: http://dx.doi.org/10.1086/209154

Benjamin, W., 'Unpacking My Library: A Talk about Book Collecting,' in Illuminations, ed. Hannah Arendt, trans. Harry Zohn, Schocken Books, New York, 1969.

Dilworth, L. (ed.), Acts of Possession: Collecting in America, ed. , Rutgers University Press, New Brunswick, NJ, 2003.
} 
Knox, S., 'The Serial Killer as Collector,' in Acts of Possession: Collecting in America, ed. Leah Dilworth, Rutgers University Press, New Brunswick, NJ, 2003.

Maertz, G.,'Exhibiting Nazi Artifacts and Challenging Traditional Museum Culture: A Conversation with Mitchell Wolfson Jr.,' in Acts of Possession: Collecting in America, ed. Leah Dilworth, Rutgers University Press, New Brunswick, NJ, 2003.

Stewart, S., On Longing: Narratives of the Miniature, the Gigantic, the Souvenir, the Collection, Duke University Press, 1993. 